UDC: 821.111.09-31 Vulf V.

\title{
WATER AS METAPHOR IN VIRGINIA WOOLF'S TO THE LIGHTHOUSE: OUT THERE IN THE FLOODS ALONE
}

\author{
DANICA IGRUTINOVIĆ 1 \\ Faculty for Media and Communications, \\ University of Singidunum, \\ Belgrade, Serbia
}

Rad analizira metaforička značenja koja ima voda u romanu Ka svetioniku Virdžinije Vulf u okviru nove mitologije vode koju je uveo modernizam putem tumačenja drevnih mitova od strane prvih antropologa i psihologa. Posebno se osvrće na simboličko putovanje preko vode, u kome voda rastače, ali zatim i regeneriše junaka.

Najznačajniji simbol u romanu, svetionik, suprotstavljanjem fluidnosti života, nastajanja, i nestajanja, ovom analizom dobija dodatna značenja.

Ključne reči: voda, metafora, Ka svetioniku, V. Vulf.

The mythology of water newly established in Modernism via interpretations and reinterpretations of ancient myths by anthropologists and psychologists has at its core the story of Nekyia, a symbolic night journey over water. The journey begins with the hero's exile from the rational, stable, civilized world, and descent into the irrational, chaotic, watery depths of the unconscious and prime matter. In this underwater Hades or Hell, the hero suffers a symbolic death, which leads to a rebirth. The depths often hide precious life-giving treasure, and the victorious hero is allowed to take the spoils with him back to the surface.

Virginia Woolf seems to have been born exiled from the safe world of stability, sanity, and rationality, and this state appears to have aggravated when she was writing To the Lighthouse. She wrote in her Diary: "after Lighthouse I was, I remember, nearer suicide, seriously, than since 1913" (Woolf 1968: 229), but promised to herself that this "trough of despair shall not, I swear, engulf me" (Woolf 1968: 364). She eventually did, however, allow the 'waters of annihilation' to engulf her, and took the peaceful surrender of a symbolic death by water, so abundantly present in her work, to literal extremes when, on 28 March 1941, she stepped into the River Ouse and drowned herself.

1 Kontakt podaci (Email): danica.igrutinovic@fmk.edu.rs 


\section{OUR FRAIL BARKS: EXILE, INSTABILITY, THE UNCONSCIOUS}

The proposed visit to the Lighthouse is often referred to in the novel as an 'expedition' and a 'journey' into the unknown, unstable, disturbing, and perilous. The abstract expedition to knowledge and truth is similarly described by Mr. Ramsay as "the passage to that fabled land where our brightest hopes are extinguished" and where "our frail barks founder in darkness" (Woolf 1964: 4). He thinks it is his fate as a philosopher "to come out thus on a spit of land which the sea is slowly eating away, and there to stand, like a desolate sea-bird, alone" (Woolf 1964: 51). Lily similarly feels it is "an odd road to be walking, this of painting. Out and out one went, further and further, until at last one seemed to be on a narrow plank, perfectly alone, over the sea" (Woolf 1964: 19).

The search for stability and meaning, the necessary work of life, the expedition or exile that is the pursuit of art or science, are all seen in the novel in terms of going out to sea and battling the watery chaos. Lily the artist, Mr. Ramsay the rationalist philosopher, and Mrs. Ramsay the wife and mother all feel they are the ones out at sea alone, while the rest of humankind is safely harbored. Mr. Ramsay "liked that men should labour and sweat on the windy beach at night, pitting muscle and brain against the waves and the wind; he liked men to work like that, and women to keep house, and sit beside sleeping children indoors, while men were drowned, out there in a storm" (Woolf 1964: 190). In almost identical terms, Mrs. Ramsay sees her work of sustaining and nurturing life as controlling the waters, battling chaos, or sailing the seas. At her party, she "began all this business, as a sailor not without weariness sees the wind fill his sail and yet hardly wants to be off again" (Woolf 1964: 97). Mr. Bankes equates Mrs. Ramsay's reading a tale to her boy with finding the solution to a scientific problem, as the result of both is that "barbarity was tamed, the reign of chaos subdued" (Woolf 1964: 55). Since both men and women, scientists and artists, feel alone at sea, there is no real contrast between them, and both seek the stability of harbor and land in the other extreme.

Water is also persistently used to express the unconscious and the internal life. A reference is made to "the lake of one's being" (Woolf 1964: 74), and the minds of men are described as "pools of uneasy water" (Woolf 1964: 153). In Poole's words, water for Virginia Woolf signifies "the deep pull of unconsciousness, easy death. Water is dissolution of the self in something greater than the self." Mrs. Ramsay's 'mystical' state is likewise for him "the death of personality in water" (Poole 1978: 266-271). The description of her mystical experience is flooded with water. Watching the light of the Lighthouse, she feels "as if it were stroking with its silver fingers some sealed vessel in her brain whose bursting would flood her with delight", and "the ecstasy burst in her eyes and waves of pure delight raced over the floor of her mind and she felt, It is enough! It is enough!" (Woolf 1864: 75-76). In her Diary, Woolf similarly depicts herself as "slipping tranquilly off into the deep water of my own thoughts navigating the underworld" (Woolf 1968: 80). Her paper "Professions for Women" uses the image of the female imagination as descending into the deepest part of the lake: "The line raced through the girl's fingers. Her imagination had rushed away. It had sought the pools, the depths, the dark places where the largest fish slumber" (Poole 1978: 265266). Consistent in her use of imagery, Woolf tends to link water with all that is removed from stability, all that is unknown, irrational, or internal. 


\section{THE MONOTONOUS FALL OF THE WAVES: NATURE, CHAOS, LIFE}

Water in To the Lighthouse represents the temporal world, the disturbingly mutable nature, and the inevitable passage of time. Mr. Ramsay feels that his eight children, offering him some hope of durability beyond his individual life, will "stem the flood a bit" (Woolf 1964: 80). Men of science, striving to impose order onto nature and achieve immortality, remove themselves from the flow of life, and Mrs. Ramsay pities them: "How much they missed, after all, these very clever men! How dried up they did become, to be sure" (Woolf 1964: 116). The stability and safety of "order and dry land" are contrasted with the chaotic state in which "things wavered and vanished, waterily" (Woolf 1964: 113).

Nature is opposed to civilization, form, and order, and often equated with water. On the Isle of Skye, Mr. Ramsay is "three hundred miles from his library and his lectures and his disciples", and Mrs. Ramsay complains that the summer house "positively dripped with wet", and is constantly invaded by the sea and nature. The children "bring the beach in with them", filling the house with sand, crabs, seaweed, shells, reeds, and stones, and as a result, "things got shabbier and got shabbier summer after summer" (Woolf 1964: 30-31). "Time Passes" shows how the unchecked fecundity of nature threatens to destroy the man-made form of the summer house: "What power could now prevent the fertility, the insensibility of nature?" (Woolf 1964: 160). Nature is perceived as animalistic, bestial, and opposed to reason: "the winds and waves disported themselves like the amorphous bulks of leviathans whose brows are pierced by no light of reason", and it seems "as if the universe were battling and tumbling, in brute confusion and wanton lust aimlessly by itself" (Woolf 1964: 156). The house is, however, through the hard work of civilizing humans, eventually "rescued from the pool of Time" (Woolf 1964: 161). The fluidity of nature and time is contrasted to the safe, dry order of civilization.

It is tempting to associate women with watery nature and men with dry civilization in the novel, as its male characters often perceive women as irrational and unable to control their emotions, believe women make civilization impossible by their charm, and rue the vagueness of their non-book-learned minds. Motherhood is further repeatedly linked with flow, temporality, and life. Mrs. Ramsay, the prolific mother, "would have liked always to have had a baby. She was happiest carrying one in her arms" (Woolf 1964: 68). Susan, another mother of many created by Woolf, says of herself: "So life fills my veins. So life pours through my limbs" (Woolf 1955: 123). Fertility is explicitly attributed to both nature and women, and denied to men. Mrs. Ramsay exudes "this delicious fecundity, this fountain and spray of life" into which "the fatal sterility of the male plunged itself, like a beak of brass, barren and bare" (Woolf 1964: 43).

All this can lead to inaccurate generalizations, founded on the false premise that 'life,' 'fertility', and 'nature' are somehow by definition positive concepts. In Blotner's view, "Exalting the feminine principle in life over the masculine, Virginia Woolf built her novel around a character embodying the life-giving role of the female. In opposition, she shows the male, both in the father and son aspect, as death-bearing - arid, sterile, hateful, and 'fatal'"' (Blotner 1956: 561). Similarly, Hafley (1970: 137) asserts that the 
"essential difference between Mr and Mrs Ramsay is that whereas he identifies himself with the land and thinks the sea a destroyer, she - like Lily Briscoe - believes that life is the sea and not the land". Both views are oversimplifications, as all the characters, male and female, share at least an ambiguity towards the sea, fluidity, and life. Mrs. Ramsay's ambivalence towards nature and life is apparent as she listens to "the monotonous fall of the waves on the beach, which [...] like a ghostly roll of drums remorselessly beat the measure of life, made one think of the destruction of the island and its engulfment in the sea" (Woolf 1964: 18).

Life is in To the Lighthouse often seen as a negative, destructive force, and is described as Mrs. Ramsay's 'old antagonist'. For Lily, while she is looking at the Ramsays, life "became curled and whole like a wave which bore one up with it and threw one down with it, there, with a dash on the beach" (Woolf 1964: 54). Women battle the fluidity of life and nature perhaps even more fiercely than men. Most of the work involved in reordering the summer house is done by women, and Mrs. Ramsay thinks that it is her husband's ruthless adherence to facts which actually threatens civilization.

\section{IN THAT UNDERWORLD OF WATERS: DEATH, DESTRUCTION, DISSOLUTION}

It is the remorseless, chaotic flow of nature and cosmic life that destroys the civilized life that we know and find comfort in. However, peace can be obtained by generally surrendering to the fluid element. Lily sees the voyagers swallowed up by the sea, and reflects: "It was so calm; it was so quiet" (Woolf 1964: 218). All the inhabitants of the summer house feel that "peace breathed from the sea to the shore", and the "sigh of all the seas breaking in measure round the isles soothed them" (Woolf 1964: 164165). Mrs. Ramsay is also soothed by the sound of the waves on the beach.

Death by drowning is often mentioned and understood to bring peace. Lily has a "headlong desire to throw herself off the cliff and be drowned" (Woolf 1964: 203) and we are also privy to Mrs. Ramsay's fantasy of the weary sailor who thinks how "had the ship sunk, he would have whirled round and round and found rest on the floor of the sea" (Woolf 1964: 97).

The three sailors who drowned in the waters between the island and the Lighthouse are mentioned, and Cam muses on their fate: "They don't feel a thing there [...] in that underworld of waters" (Woolf 1964: 211). Simultaneously, on shore, Lily sees Mrs. Ramsay's "shadow" haunting "the fields of death" (Woolf 1964: 210). Water appears to be a conduit to the Hades.

Water imagery is used to describe both the peaceful dissolution and cruel destruction by nature. In "Time Passes", destruction and dissolution are often identified with darkness, and darkness with water: "a downpouring of immense darkness began. Nothing, it seemed, could survive the flood, the profusion of darkness" (Woolf 1964: 145), swallowing every shape in it. "One feather, and the house, sinking, falling, would have turned and pitched downwards to the depths of darkness" (Woolf 1964: 160). 


\section{AFTER A NIGHT'S DARKNESS AND A DAY'S SAIL: SEA-CHANGE, REBIRTH, TREASURE}

Death by water offers the possibility of a sea-change. Cam, reflecting on the drowned sailors, uses some of the imagery from Ariel's song, and envisages them tranquil in "that underworld of waters where the pearls stuck in clusters to white sprays, where in the green light a change came over one's entire mind and one's body shone half transparent enveloped in a green cloak" (Woolf 1964: 212). Resurrection after the dissolution of the death by water is most explicitly experienced by Septimus in Mrs. Dalloway: "But he himself remained high on his rock, like a drowned sailor on a rock. [...] I went under the sea. I have been dead, and yet am now alive" (Woolf 1996: 77).

"Time Passes" contains the deaths of Prue, Andrew, and Mrs. Ramsay, the destruction of civilization in the Great War, and of the world and life by cold and cruel nature. All these are represented by the watery dissolution of the summer house into shapeless chaos. However, the light of the Lighthouse keeps shining throughout the darkness of "Time Passes", entering the house at regular intervals, and destruction is thus not complete.

The imagery used to describe the reordering of the house is that of a rebirth: "some rusty laborious birth seemed to be taking place, as the women, stooping, rising, groaning, singing, slapped and slammed" (Woolf 1964: 162). After the long night of chaos, deaths, and war, the house, civilization, and the world are resurrected, and the morning finds Lily "sitting bolt upright in bed. Awake" (Woolf 1964: 166). Significantly, Lily the painter and Mr. Carmichael the poet are the first to arrive. The resurrection is the result of hard work and artistic vision.

Apart from enabling regeneration, water also consistently yields treasure in To the Lighthouse. During her journey, Cam looks "down into the foam, into the sea with all its treasure in it" (Woolf 1964: 191), and at her dinner party, the centerpiece makes Mrs. Ramsay "think of a trophy fetched from the bottom of the sea, of Neptune's banquet" (Woolf 1964: 113).

Another trophy at the dinner party is that of achieved interpersonal unity, which is expressed in terms of water. Mrs. Ramsay is aware that "the whole of the effort of merging and flowing and creating rested on her" (Woolf 1964: 97) and successfully establishes "that community of feeling with other people which emotion gives as if the walls of partition had become so thin that practically (the feeling was one of relief and happiness) it was all one stream" (Woolf 1964: 131). Lily, smitten with her obsession for Mrs. Ramsay, wonders "What device for becoming, like waters poured into one jar, inextricably the same, one with the object one adored?" (Woolf 1964: 59).

Unity is also perceived as offering stability and opposing fluidity. At the dinner party, "here, inside the room, seemed to be order and dry land; there, outside, a reflection in which things wavered and vanished, waterily" and all present are "conscious of making a party together in a hollow, on an island; had their common cause against that fluidity" (Woolf 1964: 113).

As Mrs. Ramsay hosts her version of the Last Supper, bringing people into communion with herself and each other, so Mr. Ramsay shares a meal with fishermen, much like Christ did after His Resurrection. Fishing itself is a form of retrieving treasure 
from the sea, and can be taken to represent the cruel extraction of meaning from the fluidity of life, as performed by art or science, in the description of the baiting of the hook: "Macalister's boy took one of the fish and cut a square out of its side to bait his hook with. The mutilated body (it was alive still) was thrown back into the sea" (Woolf 1964: 209).

The crucial treasure the sea offers is the Lighthouse, reached by a night journey over water. That the Lighthouse can be arrived at "after a night's darkness and a day's sail" (Woolf 1964: 3), as young James hopes, proves to be true, for after the long night of chaos, war, and death, the expedition is finally undertaken.

The characters reach their versions of the Lighthouse in their own different ways. James actively sails the boat, while Cam narrates to herself throughout the journey. Mr. Ramsay reads his book, paying little attention to outside "reality", but Lily generously concedes that "He must have reached it" (Woolf 1964: 241). Lily, having "exchanged the fluidity of life for the concentration of painting" (Woolf 1964: 183) feels her brush is "the one dependable thing in a world of strife, ruin, chaos" (Woolf 1964: 173). She finally receives an artistic vision, and what she adds to her canvas can be interpreted as a representation of the Lighthouse: "With a sudden intensity, as if she saw it clear for a second, she drew a line there, in the centre" (Woolf 1964: 242). Mr. Carmichael publishes immortalizing poetry during the war, and Mrs. Ramsay's beauty "stilled life - froze it" (Woolf 1964: 205).

\section{MARKING THE CHANNEL: STABILITY, ORDER, BALANCE}

The "hoary Lighthouse, distant, austere" (Woolf 1964: 14), though not as clearly defined a symbol as some would wish, plainly signifies solidity that is opposed to the overwhelming fluidity of nature. Another layer of interpretation of the lighthouse symbol in Woolf's world can be fished out of The Waves. Young Rhoda plays with white petals in the basin, imagining they are ships at sea. Her later reflections on life employ the imagery from her game: "We may sink and settle on the waves. The sea will drum in my ears. The white petals will be darkened with sea water. They will float for a moment and then sink. Rolling me over the waves will shoulder me under. Everything falls in a tremendous shower, dissolving me" (Woolf 1955: 147). Rhoda stabilizes her little sea: "I will plant a lighthouse here, a head of Sweet Alice" (Woolf 1955: 13). Sweet Alice, or Alyssum maritima, belongs to the cruciferous botanical family, and its symbolic meanings include 'sanity' and 'worth beyond beauty'. It is also called 'Blessed by Mary' and 'Mary's Little Cross', as its four petals form a cross. This links it with both the Blessed Virgin Mary and Christ, the human and the divine, the feminine and the masculine.

Similarly, in To the Lighthouse, the Lighthouse represents stability, but also the middle way between rigidity and fluidity. Such is Woolf's skill in making the symbol of the Lighthouse universal, that Blotner (1956: 562), on the one hand, feels compelled to assert that "the symbol refers to Mrs. Ramsay herself", while Pedersen (1958: 585), on the other, claims that Mrs. Ramsay "is revealed as the negative force which usurps the lighthouse and thus prevents the integration of the family while she lives. Only after her death can James and Cam go to the lighthouse, and thus symbolically to their father". 
The Lighthouse in fact symbolizes both Mr. and Mrs. Ramsay, and both explicitly identify themselves with it. Mr. Ramsay sees himself as "marking the channel out there in the floods alone" (Woolf 1964: 51), and Mrs. Ramsay feels "she was stern, she was searching, she was beautiful like that light" (Woolf 1964: 74).

The truth or reality may appear like a magical and mystical fairy-tale, as it does in the feminine vision of Mrs. Ramsay, or it may equal brutal and bare facts, as it does in the masculine outlook of Mr. Ramsay. Arriving at the Lighthouse, James is initially disillusioned, for instead of the "silvery, misty-looking tower" of his childhood, he sees "the white-washed rocks; the tower, stark and straight". James, unlike either of his parents, concludes that "nothing was simply one thing. The other was the Lighthouse too" (Woolf 1964: 215-216). Mrs. Ramsay, wishing to provide the Lighthouse keeper with something to read, decides: "Croom on the Mind and Bates on the Savage Customs of Polynesia [...] neither of those could one send to the Lighthouse" (Woolf 1964: 31). Aside from being too intellectual for the simple keeper and his boy, these books also signify the extremes of civilization and savagery, intellect and myth. These do not belong in the Lighthouse, which embodies balance.

Water is so metaphorically significant in the world of To the Lighthouse that Mr. Ramsay's notion that "the depths of the sea" are "only water after all" (Woolf 1964:239) reads as a joke. Leading into exile from civilization, reason, and sanity, and towards the unknown, the unconscious, and the internal, water signifies all that is unstable, chaotic, fleeting, and temporal. It represents animalistic nature, woman as mother, and fertility and life themselves. Water is the peaceful surrender to death and annihilation, but also the cruel destruction of all forms by nature. Death by water offers the possibility of rebirth, watery depths yield the treasures of unity and meaning to those who seek them, and the night journey over water leads to eternity, fixity, and balance, embodied in the Lighthouse.

\section{REFERENCES}

Blotner, J. L. 1956. Mythic Patterns in To the Lighthouse. Publications of the Modern Language Association of America (PMLA) 71, 547-562.

Hafley, J. 1970. The Creative Modulation of Perspective. In M. Beja (ed.) Virginia Woolf: To the Lighthouse: A Selection of Critical Essays. London: Macmillan and Co. Ltd., 133148.

Pedersen, G. 1958. Vision in To the Lighthouse. Publications of the Modern Language Association of America (PMLA) 78, 585-600.

Poole, R. 1978. The Unknown Virginia Woolf. Cambridge: CUP.

Woolf, L. (ed.). 1968. A Writer's Diary: Being Extracts from the Diary of Virginia Woolf. London: The Hogarth Press.

Woolf, V. 1955. The Waves. London: The Hogarth Press.

Woolf, V. 1964. To the Lighthouse. London: J. M. Dent \& Sons Ltd.

Woolf, V. 1996. Mrs. Dalloway. London: Penguin Books. 


\section{SUMMARY}

\section{WATER AS METAPHOR IN VIRGINIA WOOLF'S TO THE LIGHTHOUSE: OUT THERE IN THE FLOODS ALONE}

This paper explores the metaphorical meanings of water in Virginia Woolf's To the Lighthouse within the mythology of water newly established in Modernism via interpretations of ancient myths by the first anthropologists and psychologists. Special regard is accorded to the symbolic journey over water, in which the hero is disintegrated, but then also regenerated by water.

The most significant symbol in the novel, the lighthouse, by being juxtaposed to the fluidity of life, becoming, and dissipation, acquires additional meanings in this analysis.

KEYWORDS: water, metaphor, To the Lighthouse, V. Woolf.

(Original scientific paper received 29.12.2010;

revised $25.04 .2011_{i}$

accepted 28.01.2012) 